\title{
Effect of Complete Denture Rehabilitation on Oral Health-related Quality of Life in Completely Edentulous Patients
}

\author{
1Jatan Patel, ${ }^{2}$ Rajesh Sethuraman, ${ }^{3}$ Paranjay Prajapati, ${ }^{4}$ Jayanti Patel
}

\begin{abstract}
Context: Oral conditions and their impacts on quality of life (QoL) are now important as a tool to evaluate patients' perception of treatment offered to them. There are various indexes used as a tool to assess the QoL of the individual. The general oral health assessment index (GOHAI) is a proven and reliable index to assess the oral health and its impact on oral healthrelated quality of life (OHRQoL).
\end{abstract}

Aim: To evaluate the effect of complete denture rehabilitation on OHRQoL in completely edentulous patients.

Settings and design: The study compares the improvement of OHRQoL of 50 completely edentulous patients enrolled in the study, after rehabilitation of them with conventional complete dentures.

Materials and methods: Hindi version of the GOHAI was used as evaluation tool for OHRQoL.

Statistical analysis: Wilcoxon signed-rank test was applied to assess changes in GOHAI score before and after rehabilitation with a complete denture.

Results: The GOHAl score was seen to be increased from $22.30 \pm 1.67$ to $27.48 \pm 1.13$ ( $p$-value $<0.000)$, which was highly significant.

Conclusion: The GOHAl is an example of a patient-based assessment of oral health problems commonly affecting older adults. The GOHAl assessment indicates improvement in chewing. The highest change between pre- and postinsertion scores was $92.75 \%$ for biting or chewing any kind of food.

Keywords: Complete denture, Geriatric oral health assessment index, Oral health-related quality of life.

How to cite this article: Patel J, Sethuraman R, Prajapati $\mathrm{P}$, Patel J. Effect of Complete Denture Rehabilitation on Oral Health-related Quality of Life in Completely Edentulous Patients. J Contemp Dent 2016;6(3):166-170.

Source of support: Nil

Conflict of interest: None

\footnotetext{
${ }^{1}$ Postgraduate Student, ${ }^{2,4}$ Professor, ${ }^{3}$ Reader

${ }^{1-4}$ Department of Prosthodontics, KM Shah Dental College and Hospital, Sumandeep Vidyapeeth, Vadodara, Gujarat, India

Corresponding Author: Paranjay Prajapati, Reader, Department of Prosthodontics, KM Shah Dental College and Hospital Sumandeep Vidyapeeth, Vadodara, Gujarat, India, e-mail: pgp2329@gmail.com
}

\section{INTRODUCTION}

The concept of "well-being" is introduced in definition proposed by the World Health Organization (WHO). "Quality of life (QoL)" defined by the WHO is: "The condition of life resulting from the combination of the effects of the complete range of factors, such as those determining health, happiness (including comfort in the physical environment and a satisfying occupation), education, social and intellectual attainments, freedom of action, justice and freedom of expression." Thus, there are clear differences between the concept of "Level of Living," which is based on objective criterions and QoL, which depends on an individual's own subjective evaluation. ${ }^{1}$

Health-related quality of life (HRQoL) could be affected by a variety of factors, for example, the past experience of health or health care systems. ${ }^{2-4}$ The general oral health assessment index (GOHAI) (Fig. 1) was developed by Atchison and Dolan in $1990^{2}$ and used in North America for elderly patients. Its internal consistency is satisfactory and its validity has been confirmed in Swedish, ${ }^{2}$ Malay, ${ }^{3}$ Arabic, ${ }^{4}$ and German ${ }^{5}$ studies. The GOHAI was originally developed as a self-reported measure to provide information about oral symptoms as well as psychosocial and functional problems related to oral health that are bothersome to patients. $^{6}$

The Indian version of GOHAI did not exist and has only been recently validated and published in 2013 . Hence, this study was planned to assess and compare the effect of complete denture on oral health-related quality of life (OHRQoL) in completely edentulous patients by the Hindi version of GOHAI. ${ }^{7}$

\section{MATERIALS AND METHODS}

This study was conducted in the Department of Prosthodontics, KM Shah Dental College and Hospital, Sumandeep Vidyapeeth, Vadodara, Gujarat, India. Patients who reported to the department were screened for inclusion criteria of the study. Patients with poor residual ridge, partial edentulous condition, single complete denture, temporomandibular disorders, and the old denture wearers were not included in the study. 
जरावस्था में मुख की स्वास्थ्य जांच सूची (Geriatric Oral Health Assessment Index)

नीचे दी गई सूची का कार्य वृद्ध मरीजों के मुख की स्वास्थ्य स्थिति को दर्ज करना है। आपके मुखे के स्वास्थ्य संबंधी अनुभव जानके के लिए आपसे बारह प्रश्न पूछे जायेंगे। हर प्रश्न के चार विकल्प हैं- कभी नहीं, कभी कभी, अधिकतर, हमेशा। कृपया इन प्रश्नों के समुचित उत्तर दें।

\begin{tabular}{|c|c|c|c|c|c|}
\hline $\begin{array}{l}\text { क्रम } \\
\text { सं. }\end{array}$ & गोहाई प्रश्न & $\begin{array}{l}\text { कभी } \\
\text { नहीं }\end{array}$ & $\begin{array}{l}\text { कभी } \\
\text { कभी }\end{array}$ & अधिकतर & हमेशा \\
\hline 1 & $\begin{array}{l}\text { आपको कितनी बार अपने दांतों या कृत्रिम दांतों की } \\
\text { समस्या के कारण खाने की प्रकृति या मात्रा में कमी } \\
\text { करनी पड़ी ? }\end{array}$ & & & & \\
\hline 2 & $\begin{array}{l}\text { आपको कितनी बार कोई सखत वस्तु जैसे मूंगफली, } \\
\text { गाजर, सेब, मूली या मांस काटने या चबाने में दिक्कत } \\
\text { हुई? }\end{array}$ & & & & \\
\hline 3 & $\begin{array}{l}\text { कितनी बार आप दांतों या कृत्रिम दांतों के रहते बिना } \\
\text { कठिनाई के निगल पाये? }\end{array}$ & & & & \\
\hline 4 & $\begin{array}{l}\text { कितनी बार आप अपने दांतों या कृत्रिम दांतों के कारण } \\
\text { वैसे नहीं बोल सके जैसे आप चाहते थे? }\end{array}$ & & & & \\
\hline 5 & $\begin{array}{l}\text { आप कितनी बार बिना कोई असुविधा महसूस किए कुछ } \\
\text { खा सके हैं? }\end{array}$ & & & & \\
\hline 6 & $\begin{array}{l}\text { आपने कितनी बार अपने दांतों, मसूड़ों या कृत्रिम दांतों } \\
\text { की दशा के कारण लोगों से मिलना जुलना कम कर } \\
\text { दिया? }\end{array}$ & & & & \\
\hline 7 & $\begin{array}{l}\text { आप कितनी बार अपने दांतों, मसूड़ों और कृत्रिम दांतों } \\
\text { की बनावट से प्रसन्न या संतुष्ट हुए? }\end{array}$ & & & & \\
\hline 8 & $\begin{array}{l}\text { आपने कितनी बार अपने दांतों, मसूड़ों या कृत्रिम दांतों } \\
\text { की असुविधा या दर्द को दूर करने के लिए दवा ली? }\end{array}$ & & & & \\
\hline$?$ & $\begin{array}{l}\text { आपको कितनी बार अपने दांतों, मसूड़ों और कृत्रिम दांतों } \\
\text { संबंधी समस्याओं को लेकर चिंता या आशंका हुई? }\end{array}$ & & & & \\
\hline 10 & $\begin{array}{l}\text { आपको कितनी बार अपने दांतों, मसूड़ों या कृत्रिम दांतों } \\
\text { की समस्या के कारण चिंतित या सचेत रहना पड़ा? }\end{array}$ & & & & \\
\hline 11 & $\begin{array}{l}\text { आपको कितनी बार अपने दांतों या कृत्रिम दांतों की } \\
\text { समस्या के कारण दूसरों के सामने खाने में असहजता } \\
\text { महसूस हुई? }\end{array}$ & & & & \\
\hline 12 & $\begin{array}{l}\text { क्या आपके दांत गर्म, ठंडे या मीठे के प्रति संवेदनशील } \\
\text { हैं? }\end{array}$ & & & & \\
\hline
\end{tabular}

Fig. 1: General oral health assessment index Hindi version 
With data values obtained from a previous study, ${ }^{8}$ sample size was obtained by using $\mathrm{N}$ master software (version 2.0 ) at $95 \%$ confidence interval and $80 \%$ power. A final sample size of 50 was obtained.

Conventional technique was used to fabricate complete denture. According to the case requirement, modification of the technique and material was carried out for the betterment of participants. Anatomic acrylic resin denture teeth were used to establish a balanced articulation. All dentures were processed in the same dental laboratory within the institution by compression molding technique and standard laboratory protocol was followed. The Hindi version of $\mathrm{GOHAI}^{9}$ questionnaire was completed by the examiner who interviewed the participants on two different occasions. Permission was taken to apply the Hindi version of GOHAI questionnaire from the authors. One questionnaire was recorded before denture insertion. When no further adjustment was required or indicated, participants were asked to return for a further review 1 month later, and the Hindi version of GOHAI was recorded by a single recorder. The 12th question that relates dental sensitivity to heat and cold was not considered for all the participants.

Although the questionnaire items are usually scored on a 5-point scale, the GOHAI was administered using a 3-point scale (always, sometimes, never). The GOHAI scale scores at baseline and after 1 month were calculated as a simple summation of the 11 items (response set is always, very often, often $=1$; sometimes, seldom $=2$; never $=3$ ) after reversing the response set of three items (item 3: Swallow comfortably; item 5: Eat anything without feeling discomfort; item 7: Happy with looks). A simple summative score ranging from 11 to 33 was calculated for each participant, with a higher score indicating better self-reported oral health. ${ }^{1}$ Score obtained was statistically evaluated.

\section{RESULTS}

In this study, 60 completely edentulous participants completed questionnaire precomplete denture insertion. A total of 10 participants did not return and were considered as drop-outs. Rest all participants completed the GOHAI questionnaire on both occasions. Thus, 50 participants completed the study. The GOHAI score before denture insertion was collected in tables and statistical analysis was performed.

The highest mean of GOHAI score at baseline was 2.96 [standard deviation $(\mathrm{SD})=0.19$ ] for taking medication for relieving pain, followed by 2.68 for nervous or self-conscious problem with teeth or gum (Table 1).

The highest mean of GOHAI score after 1 month of placement of complete denture was $2.94(\mathrm{SD}=0.24)$ for "limit your food intake." It indicates that the participants did chew food better than before, followed by 2.92 $(\mathrm{SD}=0.27)$ for "limiting contacts with people" because of the condition of teeth or dentures (Table 2).

Statistically significant difference was observed for medication used to relieve pain or discomfort from around the mouth; being worried or concerned about the problems with teeth, gums, or dentures; and for limiting the kinds or amounts of food because of problems with teeth or dentures. Factors, such as difficulty in biting or chewing food and being pleased or happy with the looks of their teeth and gums or dentures also showed a statistically significant difference (Tables 1 and 2). Limiting contacts with people and feeling nervous or self-consciousness because of problems with teeth were not found to be statistically significant.

When the overall mean was considered, the difference between pre- and postdenture insertion scores was statistically highly significant. The highest change between pre- and postinsertion scores was $92.75 \%$ for biting or chewing any kind of food.

Table 1: Change in mean GOHAl scores, i.e., preinsertion and postinsertion

\begin{tabular}{llllll}
\hline Questions no. & Preinsertion & Postinsertion & $\begin{array}{l}\text { Change in score } \\
(\text { post }- \text { pre) }\end{array}$ & Wilcoxon (W) & $p$-value \\
\hline 1 & $1.88 \pm 0.44$ & $2.94 \pm 0.24$ & 1.06 & -1035 & 0.000 \\
2 & $1.38 \pm 0.49$ & $2.66 \pm 0.48$ & 1.28 & -1035 & 0.000 \\
3 & $2.30 \pm 0.50$ & $2.78 \pm 0.42$ & 0.48 & -325 & 0.000 \\
4 & $1.40 \pm 0.64$ & $2.76 \pm 0.43$ & 1.36 & -1039 & 0.000 \\
5 & $2.56 \pm 0.64$ & $1.14 \pm 0.35$ & -1.42 & 1017 & 0.000 \\
6 & $1.88 \pm 0.77$ & $2.92 \pm 0.27$ & 1.04 & -682 & 0.000 \\
7 & $1.04 \pm 0.18$ & $1.06 \pm 0.24$ & 0.02 & -3 & 0.7656 \\
8 & $2.96 \pm 0.19$ & $2.6 \pm 0.49$ & -0.36 & -228 & 0.000 \\
9 & $2.54 \pm 0.50$ & $2.92 \pm 0.27$ & 0.38 & -21 & 0.000 \\
10 & $2.68 \pm 0.47$ & $2.72 \pm 0.45$ & 0.04 & -1128 & 0.6702 \\
11 & $1.68 \pm 0.55$ & $2.98 \pm 0.14$ & 1.3 & -1.75 & 0.000 \\
Q1-Q11 & $22.3 \pm 1.67$ & $27.48 \pm 1.13$ & 5.18 & & 0.000 \\
\hline
\end{tabular}


Effect of Complete Denture Rehabilitation on Oral Health-related Quality of Life in Completely Edentulous Patients

Table 2: Change in GOHAl score before and after insertion tested using Wilcoxon signed-rank test

\begin{tabular}{|c|c|c|c|c|c|c|}
\hline \multirow[b]{2}{*}{ Questions no. } & \multicolumn{2}{|c|}{ Preinsertion } & \multicolumn{2}{|c|}{ Postinsertion } & \multirow[b]{2}{*}{$p$-value } & \multirow[b]{2}{*}{ Inference } \\
\hline & Median & Interquartile range & Median & Interquartile range & & \\
\hline 1 & 2 & 0 & 3 & 0 & 0.000 & $\mathrm{HS}$ \\
\hline 2 & 1 & 0 & 3 & 0 & 0.000 & HS \\
\hline 3 & 2 & 1 & 3 & 0 & 0.000 & HS \\
\hline 4 & 1 & 1 & 3 & 0 & 0.000 & HS \\
\hline 5 & 3 & 0 & 1 & 0 & 0.000 & HS \\
\hline 6 & 2 & 0 & 3 & 0 & 0.000 & HS \\
\hline 7 & 1 & 0 & 1 & 0 & 0.766 & NS \\
\hline 8 & 3 & 0 & 3 & 0 & 0.000 & HS \\
\hline 9 & 3 & 0 & 3 & 0 & 0.000 & HS \\
\hline 10 & 3 & 0 & 3 & 0 & 0.670 & NS \\
\hline 11 & 2 & 1 & 3 & 0 & 0.000 & HS \\
\hline Q1-Q11 & 23 & 1 & 22.7 & 1 & 0.000 & HS \\
\hline
\end{tabular}

HS: Highly significant; NS: Nonsignificant

\section{DISCUSSION}

This study presents the results of a self-reported GOHAI. As the name implies, this is an assessment tool, not an objective measure of the patient's oral health status. The GOHAI should not be used in place of a clinical oral examination or dental radiographs, which provide objective measures of disease.

The elderly participants of this study showed that the major problem for them lay with the physical functioning and pain and discomfort. Therefore, the items "Discomfort during eating," "Have to limit food intake/choice of food," and "Trouble biting/chewing" were mostly answered affirmatively. Least problems were found with "Limit contact with people" (probably due to indifference to esthetics), "Able to swallow properly" (mixed sample with nondenture wearers), and "Uncomfortable eating in front of others." This pattern of most concern toward the physical and psychosocial functioning may be due to the high number of participants requiring multiunit prosthesis. The frequency for the need of multiunit prosthesis or full prosthesis in the participants was found to be high, but the prosthesis wear was low. The low proportion of denture wearers may be due to the fact that older people do not use dental health care services adequately due to lack of awareness, financial constraints, and reduced mobility. Participants having removable dentures had a better GOHAI score than those without dentures. Veyrune et $\mathrm{al}^{8}$ showed that patients with the lowest initial GOHAI score derived the greatest benefit from placement of new dentures, indicating that the decision to make them should not be based only on a clinical evaluation. It is necessary to take into account their QoL and subjectively perceived needs.

There was a decrease in the mean GOHAI score for dentures preventing speech after denture insertion. This is because we know speaking normally with dentures requires practice. This result may have been obtained as a result of the short follow-up period of the study. There was an overall increase in the mean GOHAI scores 1 month after placement of complete dentures, which was highly significant. In a similar study, Veyrune et $\mathrm{al}^{8}$ reported no difference in GOHAI scores 6 weeks after placement of the new dentures and a significant increase in the GOHAI scores 12 weeks after placement. These results emphasize the importance of a follow-up of patients during the period of adaptation that is essential for the psychological and functional integration of the new prostheses. ${ }^{10}$

A similar study analyzed 27 patients from the age group 60 to 84 where the GOHAI score was seen to be increased from 27.48 to 30.19 ( $p=0.002$ ), which was highly significant. ${ }^{1}$ Another study examined 63 patients from the age group 60 to 82 , where the GOHAI score was seen to be increased from $28.90 \pm 7.28$ to $42.19 \pm 7.60$ (p-value $<0.001$ ), which was highly significant ${ }^{11}$; whereas the present study examined 50 patients from the age group 60 to 82 , where the GOHAI score was seen to be increased from $22.30 \pm 1.67$ to $27.48 \pm 1.13$ (p-value $<0.000$ ), which was highly significant.

Published literature reports that implant-supported dentures, either complete overdenture or fixed complete denture, significantly improves the QoL for edentulous patients compared with conventional removable complete dentures. For older edentulous subjects, the general health and financial status are of concern while preferring implant-retained overdentures over conventional dentures. ${ }^{12}$

One of the limitations of this study with OHRQoL regarding patient satisfaction is that the length of the follow-up period should have been considered because some patients require a longer period of time for adjustment with dentures. Further studies with a longer time of evaluation should be planned. 


\section{REFERENCES}

1. Shigli K, Hebbal M. Assessment of changes in oral healthrelated quality of life among patients with complete denture before and 1 month post-insertion using Geriatric Oral Health Assessment Index. Gerodontology 2010 Sep;27(3):167-173.

2. Atchison KA, Dolan TA. Development of the Geriatric Oral Health Assessment Index. J Dent Educ 1990 Nov;54(11): 680-687.

3. Hägglin C, Berggren U, Lundgren J. A Swedish version of the GOHAI index. Psychometric properties and validation. Swed Dent J 2005;29(3):113-124.

4. Othman WN, Muttalib KA, Bakri R, Doss JG, Jaafar N, Salleh NC, Chen S. Validation of the Geriatric Oral Health Assessment Index in the Malay language. J Public Health Dent 2006 Summer;66(3):199-204.

5. Daradkeh S, Khader YS. Translation and validation of the Arabic version of the Geriatric Oral Health Assessment Index (GOHAI). J Oral Sci 2008 Dec;50(4):453-459.

6. Hassel AJ, Rolko C, Koke U, Leisen J, Rammelsberg P. A German version of the GOHAI. Community Dent Oral Epidemiol 2008 Feb;36(1):34-42.
7. Murariu A, Hanganu C, Bobu L. Evaluation of the reliability of the geriatric oral health assessment index (GOHAI) in institutionalized elderly in Romania: a pilot study. OHDMBSC 2010 Mar;9(1):11-15.

8. Veyrune JL, Tubert-Jeannin S, Dutheil C, Riordan PJ. Impact of new prostheses on the oral health related quality of life of edentulous patients. Gerodontology 2005 Mar;22(1):3-9.

9. Mathur VP, Jain V, Pillai RS, Kalra S. Translation and validation of Hindi version of Geriatric Oral Health Assessment Index. Gerodontology 2016;33:89-96.

10. Fillion $\mathrm{M}$, Aubazac $\mathrm{D}$, Bessadet $\mathrm{M}$, Allègre M, Nicolas $\mathrm{E}$. The impact of implant treatment on oral health related quality of life in a private dental practice: a prospective cohort study. Health Qual Life Outcomes 2013 Nov;11:197.

11. Dable RA, Nazirkar GS, Singh SB, Wasnik PB. Assessment of oral health related quality of life among completely edentulous patients in Western India by using GOHAI. J Clin Diagn Res 2013 Sep;7(9):2063-2067.

12. Lemos MM, Zanin L, Jorge ML, Flório FM. Oral health conditions and self-perception among edentulous individuals with different prosthetic status. Braz J Oral Sci 2013 Mar;12(1):5-10. 